Potravinarstvo Slovak Journal of Food Sciences

vol. 13, 2019, no. 1, p. 831-839

https://doi.org/10.5219/1160

Received: 2 July 2019. Accepted: 25 October 2019.

Available online: 28 November 2019 at www.potravinarstvo.com

(C) 2019 Potravinarstvo Slovak Journal of Food Sciences, License: CC BY 3.0

ISSN 1337-0960 (online)

\title{
IMPROVEMENT OF GROWTH, PRODUCTIVITY AND SOME CHEMICAL PROPERTIES OF HOT PEPPER BY FOLIAR APPLICATION OF AMINO ACIDS AND YEAST EXTRACT
}

\author{
Amina Aly, Noha Eliwa, Mohamed Hassan Abd El Megid
}

\begin{abstract}
A greenhouse experiment was conducted during the seasons of 2016 - 2017 to compare the impact of foliar amino acids binding $\left(0.5,1\right.$ and $\left.2 \mathrm{~g} . \mathrm{L}^{-1}\right)$ and yeast extract $\left(2.5,5\right.$ and $\left.10 \mathrm{~g} . \mathrm{L}^{-1}\right)$ on certain development and physiological parameters of hot pepper (Capsicum annuum L.). The results cleared that foliar application of amino acid ( 2 g.L $\left.L^{-1}\right)$ or yeast (10 g.L - $\left.^{-1}\right)$ increased development parameters of hot pepper compared to control in both first and second seasons. Amino acids foliar implementation with $\left(2\right.$ g. $\left.\mathrm{L}^{-1}\right)$ gave higher content of anthocyanins, ascorbic acid, lycopene and B-carotene contents as compared with the control. Also, 10 g. $\mathrm{L}^{-1}$ foliar application of yeast extract showed the best results as compared to control in both first and second seasons. Foliar application of amino acids contents increased phenol and flavonoid contents of hot pepper fruits. Maximum increase was observed at 2 g.L-1 amino acids in both seasons. While 1,1-Diphenyl-2picrylhydrazyl (DPPH) and lipid peroxidation contents increased with 2 g.L.-1 amino acids and 10 g.L. . $^{-1}$ yeast foliar application. The HPLC analysis of ethanolic extract of hot pepper fruits has shown fifteen phenolic compounds. Phenolic compounds were increased by increasing the concentration of amino acid and yeast extract foliar application in the both two seasons. In conclusion it is recommended to use amino acid $\left(2\right.$ g.L. $\left.{ }^{-1}\right)$ and yeast extract $\left(10\right.$ g.L $\left.\mathrm{L}^{-1}\right)$ foliar application as they play a key role in productivity, also in protecting the environment as eco-friendly and cost-effective inputs for the farmers.
\end{abstract}

Keywords: hot pepper plant; amino acids; yeast extract; active compounds; phenolic compounds; HPLC

\section{INTRODUCTION}

One of the traditional plants that has so many pharmacology effects is chilli fruit (Capsicum sp.) which belong to the family Solanaceae. Chilli pepper and their isolated constituents including capsaicinoids have shown also beneficial therapeutic effects, including antioxidant, anti-inflammatory, anticancer, antimicrobial and antiimmune modulator effects (Popelka et al. 2017). Hot pepper (Capsicum annum L.) is a significant global horticultural plant and gives food taste, flavour and colour (Caporaso et al., 2013). It is well recognized for its elevated bioactive content, powerful antioxidant ability and is one of world's most famous new foods owing to its mixture of colour, aroma and dietary importance. Also, it is considered a good source of bioactive compounds, such as vitamins, pro-vitamins, and antioxidant compounds (Martínez et al., 2007). The plant is indigenous to North and South America, is most efficient in hot, dry environment and is used in Africa and other nations of the globe for medicinal purposes (Igbokwe, Aniakor and Anagonye, 2013). Pepper fruit includes various compounds that may contribute total antioxidant capacity (TAC), including flavonoids, phenolics, ascorbates, carotenoids, and capsaicinoids (Palma et al., 2015). In defence against biotic and abiotic stress the significant functions of crop phenolics emerged. They demonstrated broad variety of biological operations, including antithrombotic, antibacterial, anti-inflammatory, antiallergic, hepatoprotective, antiviral, vasodilatory and anticarcinogenic (Soobrattee et al., 2005). The option of using natural secure agents to stimulate development and output of vegetable plants has been a major problem nowadays. During crop development phases, the application of bio-fertilization to plants was thought to be a good option to chemical fertilization. Bio-fertilizers are microbial structures comprising living bodies of separate microorganisms that have the capacity to mobilize crop nutrients in the land from unusable to usable shape. It is regarded eco-friendly, plays a major part in the manufacturing of crops, helps to construct the missed microorganisms and improves oil health (Zhang et al., 2013). In the same regard Mahmoud and Hafez (2010) 
disclosed that, bio-fertilizers increased crop yields by $20 \%$ $-30 \%$, improved plant development and optimized ground biological activity environment. Biostimulants use as amino acids and yeast extract boost crop development overcoming the damaging impact of some environmental pressure. The significance of amino acids is primarily due to their wide spread use as pigments, vitamins, coenzymes, purine and pyrimidine bases for the biosynthesis of a wide range of development and non-protein nitrogenous products. Many researches have verified that amino acids can have a direct or indirect impact on crop development and yield physiological operations (Mohamed, 2006). Yeast extract is a wealthy source of many development products (riboflavin, thiamine, pyridoxine, niacin, and vitamins B1, B2, B3 and B12), cytokinin's and many of the natural compounds such as protein, carbohydrates, nucleic acid and lipids. Dry yeast foliar application had a positive impact on plant development, output and chemical structure (Mohamed, 2005).

\section{Scientific hypothesis}

Hot pepper is well known for its high bioactive content and strong antioxidant capacity and considers as one of most popular fresh products in the world due to its combination of colour, flavour and dietary importance. This research aims to explore the effect of bio-fertilizer (amino acids and yeast extract) on certain hot pepper (Capsicum annuum L.) physiological and biochemical parameters.

\section{MATERIAL AND METHODOLOGY}

\section{Chemicals}

All reagents from Sigma-Aldrich S.P.A. (Milan, Italy) were acquired and had an elevated degree of hardness (purity $>97 \%$ ).

This experiment was conducted in the greenhouse belonging to the Natural Products Dept., National Center for Radiation Research and Technology. Nasr- city, CairoEgypt, from April to August 2016 - 2017 to assess the impact of amino acids and yeast extract foliar implementation on some physiological and chemical parameters of hot pepper (Capsicum annuum L.). Hot pepper seeds of (variety: Muria, Batch: 6800) planted with peat moss in small pot $(5 \mathrm{~cm})$. When the seedlings had $(2-3)$ real leaves, they were transported to the greenhouse where they placed $70 \mathrm{~cm}$ apart and $40 \mathrm{~cm}$ between plants on both ends of the rows. All environmental requirements have been fulfilled and agricultural needs were done. The experimental site's soil mechanical and chemical assessment is displayed in Table 1.

The levels of amino acids $\left(0.5,1.0\right.$ and 2.0 g.L. $\left.\mathrm{L}^{-1}\right)$ or yeast extract $\left(2.5,5.0\right.$ and 10.0 g.. $\left.\mathrm{L}^{-1}\right)$ were tested, the first was released one month after the plants transferred to the greenhouse then sprinkle early in the morning frequently every week until the fruiting phase. After 70 days vegetative characters of plants such as: plant height, fruit size, fruit diameter, complete amount of fruit/plant, fresh weight of one fruit $(\mathrm{g})$ and dry weight of fruits $(\mathrm{g})$ were evaluated after 70 days.

The fruits of both two seasons were cut and homogenized using liquid nitrogen and weighed at a part of $(25 \mathrm{~g})$ and then lyophilized for 48 hours (Virtis model 10-324). The samples were ground to pass a $0.5-\mathrm{mm}$ sieve and stored at $-20{ }^{\circ} \mathrm{C}$ until the analysing the bioactive materials.

Table 1 Soil mechanical and chemical analysis of the experimental site.

\begin{tabular}{lcc}
\hline \multicolumn{1}{c}{ Soil properties } & \multicolumn{2}{c}{ Experimental year } \\
\hline & $\begin{array}{c}\text { Soil properties } \\
\mathbf{2 0 1 6}\end{array}$ & $\begin{array}{c}\text { Soil properties } \\
\mathbf{2 0 1 7}\end{array}$ \\
\hline $\mathrm{pH}(1: 1)$ & & \\
$\mathrm{EC}(1: 1) \mathrm{dS} . \mathrm{m}^{-1}$ & 7.32 & 7.31 \\
Soluble anions & 2.2 & 1.8 \\
$\left(\mathrm{meq}_{\mathrm{L}} \mathrm{L}^{-1}\right)$ & & \\
$\mathrm{CO}_{3}$ & & \\
$\mathrm{HCO}_{3}$ & 1.5 & 1.3 \\
$\mathrm{Cl}$ & 4.5 & 3.6 \\
$\mathrm{SO}_{4}$ & 8.0 & 5.9 \\
$\mathrm{Soluble} \mathrm{cations}_{\left(m e q . L^{-1}\right)}$ & 11.7 & 9.8 \\
$\mathrm{Ca}^{+}$ & 10.5 & 9 \\
$\mathrm{Mg}^{++}$ & 3.5 & 2 \\
$\mathrm{~K}^{+}$ & 0.50 & 0.4 \\
$\mathrm{Na}^{+}$ & 11.2 & 9.2 \\
$\mathrm{Sand}_{(\%)}$ & 57.3 & 58.4 \\
$\left.\mathrm{Silt}^{+} \%\right)$ & 21.2 & 18.2 \\
Clay (\%) & 21.5 & 23.4 \\
Texture class & Sandy clay loam & Sandy clay loam \\
\hline
\end{tabular}

\section{Total phenolics content}

Phenolic content was analysed using the Folin-Denis reagent in accordance with Shahidi and Naczk (1995) technique. A one $\mathrm{mL}$ of sample extract was mixed with $0.5 \mathrm{~mL}$ of Folin-Denis and $1.0 \mathrm{~mL}$ of concentrated $\mathrm{Na}_{2} \mathrm{CO}_{3}$ solution, adding $3.0 \mathrm{~mL}$ of distilled water. The absorbance was evaluated at $725 \mathrm{~nm}$ (Jasco V530, Japan) against the blank after an hour. The outcome results were displayed as gallic acid equivalents, in $\mathrm{mg} .100 \mathrm{~g}^{-1}$ D.W.

\section{Flavonoids content}

In the extracts the content of flavonoids were determined by aluminium chloride colorimetric assay as mentioned by Marinova, Ribarova and Tanassova, (2005). The absorbance was measured against the blank at $510 \mathrm{~nm}$. Total flavonoids were shown as gallic acid equivalents, in mg. $100 \mathrm{~g}^{-1}$ D.W.

\section{Analysis of phenolic compounds by HPLC}

The methanolic extract was conducted by re-dissolving $100 \mathrm{mg}$ of sample in $1.0 \mathrm{~mL}$ of methanol (80 percent) and filtering through a $0.2 \mu \mathrm{m}$ filter sterilized membrane prior to HPLC assessment. Injection with $50 \mathrm{pJ}$ set circuit using Rheodyne injection values (Model 7125). Tow portable phases used a steady stream frequency of $1 \mathrm{~mL} \cdot \mathrm{min}^{-1}$ : (A) $0.5 \%$ acetic acid in distilled fluid at $\mathrm{pH}(2.65)$ and $0.5 \%$ acetic acid in $99.5 \%$ acetonitrile liquid (B). The elution gradient was linear from (A) to (B) over 50 min, using a $254 \mathrm{~nm}$ wavelength UV detector. Phenolic compound identification was performed by comparing retention times and spectral information with authentic standards 


\section{Lipid peroxidation content}

As outlined by Buege and Aust (1978), the amount of lipid peroxidation in the samples was determined as reactive metabolites 2-thiobarbituric acid (TBA) mainly malondialdehyde (MDA). Absorbance of pink colour was assessed at $532 \mathrm{~nm}$ and adjusted by subtracting the absorbance at $600 \mathrm{~nm}$ ((Jasco V530, Japan) for nonspecific turbidity. The concentration was calculated based on A532 - A $600\left(\Sigma=155 \mathrm{mM}^{-1} \mathrm{~cm}^{-1}\right)$, the MDA level was calculated. The obtained results have been displayed as $\mu$ mol.g-1 FW.

\section{Scavenging activity by 2,2-diphenyl-1- picrylhydrazyl (DPPH)}

The radical Scavenging activity on radical DPPH extracts against 2,2- Diphenyl-1-picryl hydrazyl (DPPH) radical scavenging activity was determined as outlined by Gulluce et al. (2004). Add $0.5 \mathrm{~mL}$ of each sample to $1.0 \mathrm{~mL}$ of DPPH $(2 \mathrm{mM})$ ethanolic solution. The absorbance was plotted at $517 \mathrm{~nm}$ (Jasco V530, Japan) against the background after $30 \mathrm{~min}$ of the incubation.

\section{Anthocyanins content}

The content of anthocyanins was determined using acidified methanol $(1 \% \mathrm{HCl})$. As mentioned by Fuleki and Francis (1968) and modified by Du and Francis (1973), the samples were evaluated spectrophotometrically at $535 \mathrm{~nm}$ (Jasco V-530, Japan) where the molecular weight of cyaniding-3-Oglucoside $449.2{\mathrm{~g} . \mathrm{mol}^{-1}}^{-1}$ and the molar extinction coefficient index $\left(26.900 \mathrm{~L} . \mathrm{mol}^{-1} \cdot \mathrm{cm}^{-1}\right)$ the results are expressed as $\mathrm{mg} .100 \mathrm{~g}^{-1} \mathrm{~F} . \mathrm{W}$.

\section{Ascorbic acid content}

The content of ascorbic acid was measured using the method of titration of 2,6-dichlorophenol indophenols (A.O.A.C., 2000). The results are expressed as $\mathrm{mg} .100 \mathrm{~g}^{-1}$ F.W.

\section{Hot pepper fruits- extraction}

Ethanol was used to prepare the sample extracts as described by (Nuutila et al., 2003). A ground sample $(2.0 \mathrm{~g})$ was extracted with ethanol $(25 \mathrm{~mL})$ by stirring for one night at room temperature. The blend was centrifuged for 20 minutes at $3000 \mathrm{rpm}$, with an extra $25 \mathrm{~mL}$ ethanol and the supernatant decanted. The mixed supernatant of the two extractions was used for assessment as outlined below.

\section{$\beta$ - Carotene and lycopene content}

For determining $\beta$-Carotene and lycopene the technique of (Nagata and Yamashita, 1992) was used. The dried ethanol sample $(100 \mathrm{mg})$ was stirred for $1 \mathrm{~min}$ with $10 \mathrm{~mL}$ of acetone: n-hexane mixture (4:6) for $1 \mathrm{~min}$ and filtered by Whatman filter paper No.4. The filtrate absorption was evaluated at 453, 505, 645 and $663 \mathrm{~nm}$. The $\beta$-carotene and lycopene contents were calculated as follow:

Lycopene $\left(\mathrm{mg} .100 \mathrm{~mL}^{-1}\right)=-0.0458 \mathrm{~A}_{663}+0.204 \mathrm{~A}_{645}+$ $0.372 \mathrm{~A}_{505}-0.0806 \mathrm{~A}_{453}$

$\beta$-Carotene $\left(\mathrm{mg} .100 \mathrm{~mL}^{-1}\right)=0.216 \mathrm{~A}_{663}-1.22 \mathrm{~A}_{645}-$ $0.304 \mathrm{~A}_{505}+0.452 \mathrm{~A}_{453}$

The outcomes were given as extract $\left(\mu \mathrm{g} . \mathrm{g}^{-1} \mathrm{D} . \mathrm{W}\right.$.)

\section{Statistic analysis}

Data were evaluated using difference statistical software evaluation (ANOVA) and multiple range technique used by Duncan to compare any important variations between samples. Mean scores for Duncan's multi-range experiment using IBM SPSS software 24 as a statistical resource was compared to $p<0.05$ important point (Duncan, 1955).

\section{RESULTS AND DISCUSSION}

\section{Growth parameters}

Regarding to the role of the foliar implementation of biofertilizer (amino acids and yeast extract) on growth parameter of hot pepper, Table 2 presented that there was gradual increase in plant height occurred by increasing the amino acids concentration and reached to the maximum increase in the concentration $\left(2\right.$ g. $\left.\mathrm{L}^{-1}\right)$ in the first and second seasons 62.8 and $64.4 \mathrm{~cm}$, respectively. Same trend was observed when yeast extract was applied and the highest increase was recorded in the highest concentration of yeast extract $\left(10 \mathrm{~g} . \mathrm{L}^{-1}\right)$ for the both seasons (59.6 and $62.1 \mathrm{~cm}$ ), respectively. Otherwise other vegetative growth parameters were significantly influenced by the all used amino acids concentrations and the most stimulatory effect happen in the concentration $\left(2 \mathrm{~g} . \mathrm{L}^{-1}\right)$ for fruit length $(5.9 \mathrm{~cm})$, fruit diameters $(1.8 \mathrm{~cm})$, fruit number/plant (71), fresh weight of fruit $(2.9 \mathrm{~g})$ and dry weight of fruits $(1.8 \mathrm{~g})$, respectively in the first season and same trend was observed in the second season. Yeast extract treatment caused a positive effect on the fruit length, fruit diameters, fruit number/plant, fresh weight of fruit and dry weight of fruits of hot pepper, comparable to control treatments in the two periods. Because of the immediate function of amino acids in enhancing the tissue materials of proteins and vital enzymes for managing cellular activities or activating antioxidants, the use of foliar implementation of amino acids on crop shooting is one of the contemporary techniques used to enhance crop development and production. These findings may be due to the reality that yeast extract as a natural source of protein, cytokinins stimulates cell division and enlargement as well as the synthesis of protein, nucleic acid and chlorophyll. All of these promoting substances by yeast extract were produced highly improvement of different growth parameters which exhibited on high values of fruit length, fruit diameters, fruit number/plant, fresh weight of fruit and dry weight of fruits of hot pepper. Marhoon and Abbas (2015) outlined that the use of amino acids has resulted in a clear rise in plant height and number of branches of sweet pepper stems as their concentration rises. Because of their immediate function in enhancing the tissue materials of proteins and vital enzymes for managing cellular activities or activating antioxidants, the use of foliar implementation of amino acids on crop shooting is one of the contemporary techniques used to enhance crop development and production (Cerdán et al., 2009). Meanwhile, Serna et al. (2012) have been discovered that spraying of pepper fruits with a combination of amino acids has resulted in an increased photosynthesis effectiveness, giving the greatest development in vegetative. Furthermore, Korkmaz et al. (2012) investigated that the use of amino acids contributed to a 
marked rise in fruit height, amount of leaves and dry shoot weight relative to untreated plants. Otherwise, Shafeek, Ellaithy and Helmy (2014) stated that, all hot pepper parameters were gradually and substantially improved in the first and second seasons by raising the yeast extract concentration in spraying solution from 2 g.L $\mathrm{L}^{-1}$ up to 4 g.L1 . Furthermore, enhancing the vegetative development of hot pepper crop by raising the yeast extract level may result in yeast residues being an element of nature containing cytokinins and many secure, safe and nonpollutant nutrient components. In the same concern, Maraei, Eliwa and Aly (2019) confirmed that the use of plant biostimulants has positive effects on growth and bioactive compounds in sweet pepper plants, especially when used at appropriate concentrations. The influence was evaluated through the response of vegetative growth, and some physical and chemical characteristics of sweet pepper fruits.

\section{Phenols and flavonoids contents}

As shown in Figures 1 and 2, there were significant increases caused by amino acids foliar implementation and the best values were observed at 2 g. $\mathrm{L}^{-1}$ amino acids (448 and 237 mg. $100 \mathrm{~g}^{-1}$ D.W.) for phenol and flavonoids, respectively in first season and same trend was noticed in the second season. Whereas, 10 g.L $\mathrm{L}^{-1}$ foliar application of yeast extract resulted in the highest content of phenols and flavonoids in the both two seasons.

\section{Profile of phenolic compounds by HPLC}

Fifteen phenolic compounds have been shown in the HPLC profile of methanolic extract of hot pepper fruits (Table 3). Foliar application of amino acid $\left(2\right.$ g. $\left.\mathrm{L}^{-1}\right)$ and yeast extract $\left(10\right.$ g. $\left.\mathrm{L}^{-1}\right)$ enhanced most of the phenolic compounds. The most abundant phenolic compounds were; $P$-Hydroxy benzoic acid, Caffeine, Ferulic acid, $P$ Coumaric acid, Salicylic acid, Ellagic acid, Benzoic acid and $O$-Coumaric acid.

Table 2 Effect of foliar application of amino acids and yeast extract on morphological character of hot pepper plant.

\begin{tabular}{|c|c|c|c|c|c|c|c|}
\hline \multicolumn{2}{|c|}{ Treatment } & $\begin{array}{l}\text { Plant height } \\
(\mathbf{c m} \pm S D)\end{array}$ & $\begin{array}{c}\text { Fruit } \\
\text { length } \\
(\mathrm{cm} \pm S D) \\
\end{array}$ & $\begin{array}{l}\text { Fruit diameter } \\
\quad(\mathrm{cm} \pm S D)\end{array}$ & $\begin{array}{c}\text { Total no. of } \\
\text { fruit/plant } \\
\pm S D \\
\end{array}$ & $\begin{array}{c}\text { Fresh weight of } \\
\text { one fruit } \\
(\mathrm{g} \pm S D) \\
\end{array}$ & $\begin{array}{c}\text { Dry weight of } \\
\text { one fruit } \\
(\mathrm{g} \pm S D) \\
\end{array}$ \\
\hline \multicolumn{8}{|c|}{ First season } \\
\hline \multirow{4}{*}{$\begin{array}{l}\text { Amino } \\
\text { acid }\end{array}$} & Control & $50.1 \pm 0.90 \mathrm{E}$ & $5.0 \pm 0.49 \mathrm{C}$ & $1.1 \pm 0.11 \mathrm{E}$ & $55 \pm 1.8944 \mathrm{~F}$ & $2.1 \pm 0.089 \mathrm{D}$ & $0.42 \pm 0.08 \mathrm{E}$ \\
\hline & 0.5 g. $\mathrm{L}^{-1}$ & $52.3 \pm 1.89 \mathrm{E}$ & $5.2 \pm 0.89 \mathrm{CB}$ & $1.3 \pm 0.19 \mathrm{CD}$ & $58 \pm 1.894 \mathrm{E}$ & $2.4 \pm 0.187 \mathrm{C}$ & $0.48 \pm 0.08 \mathrm{D}$ \\
\hline & 1 g. $\mathrm{L}^{-1}$ & $53.4 \pm 1.97 \mathrm{D}$ & $5.3 \pm 0.78 \mathrm{~B}$ & $1.4 \pm 0.15 \mathrm{C}$ & $59 \pm 1.897 \mathrm{DE}$ & $2.6 \pm 0.178 \mathrm{BC}$ & $0.50 \pm 0.067 \mathrm{CD}$ \\
\hline & 2 g. $L^{-1}$ & $62.8 \pm 1.7 \mathrm{~A}$ & $5.9 \pm 0.78 \mathrm{~A}$ & $1.8 \pm 0.18 \mathrm{~A}$ & $71 \pm 1.788 \mathrm{~A}$ & $2.9 \pm 0.167 \mathrm{~A}$ & $0.58 \pm 0.04 \mathrm{~A}$ \\
\hline \multirow{3}{*}{$\begin{array}{l}\text { Yeast } \\
\text { extract }\end{array}$} & $2.5 \mathrm{~g} . \mathrm{L}^{-1}$ & $54.9 \pm 1.5 \mathrm{CD}$ & $5.3 \pm 0.516 \mathrm{~B}$ & $1.4 \pm 0.17 \mathrm{C}$ & $60 \pm 2.516 \mathrm{D}$ & $2.6 \pm 0.189 \mathrm{BC}$ & $0.52 \pm 0.08 \mathrm{C}$ \\
\hline & 5 g. $L^{-1}$ & $56.0 \pm 1.87 \mathrm{C}$ & $5.4 \pm 0.51 \mathrm{~B}$ & $1.6 \pm 0.18 \mathrm{AB}$ & $65 \pm 1.894 \mathrm{C}$ & $2.7 \pm 0.109 \mathrm{BA}$ & $0.54 \pm 0.04 \mathrm{~B}$ \\
\hline & 10 g.L $\mathrm{L}^{-1}$ & $59.6 \pm 1.89 \mathrm{~B}$ & $5.6 \pm 0.894 \mathrm{~B}$ & $1.7 \pm 0.18 \mathrm{~A}$ & $68 \pm 1.890 \mathrm{~B}$ & $2.8 \pm 0.183 \mathrm{BA}$ & $0.56 \pm 0.09 \mathrm{AB}$ \\
\hline \multicolumn{2}{|c|}{ LSD } & 1.9027 & 0.2178 & 0.1499 & 1.9672 & 0.229 & 0.0223 \\
\hline \multicolumn{8}{|c|}{ Second season } \\
\hline \multirow{4}{*}{$\begin{array}{l}\text { Amino } \\
\text { acid }\end{array}$} & Control & $53.1 \pm 1.89 \mathrm{E}$ & $5.2 \pm 0.83 \mathrm{D}$ & $1.5 \pm 0.18 \mathrm{E}$ & $59 \pm 1.894 \mathrm{E}$ & $2.3 \pm 0.178 \mathrm{C}$ & $0.46 \pm 0.016 \mathrm{D}$ \\
\hline & 0.5 g. $\mathrm{L}^{-1}$ & $55.3 \pm 1.51 \mathrm{D}$ & $5.4 \pm 0.78 \mathrm{D}$ & $1.7 \pm 0.15 \mathrm{D}$ & $60 \pm 2.516 \mathrm{DE}$ & $2.4 \pm 0.144 \mathrm{C}$ & $0.50 \pm 0.053 \mathrm{C}$ \\
\hline & 1 g. $\mathrm{L}^{-1}$ & $57.7 \pm 1.89 \mathrm{C}$ & $5.7 \pm 0.89 \mathrm{C}$ & $1.8 \pm 0.17 \mathrm{CD}$ & $62 \pm 1.788 \mathrm{DC}$ & $2.8 \pm 0.189 \mathrm{~B}$ & $0.56 \pm 0.197 \mathrm{~B}$ \\
\hline & 2 g.L - $^{-1}$ & $64.4 \pm 1.51 \mathrm{~A}$ & $6.37 \pm 0.51 \mathrm{~A}$ & $2.1 \pm 0.16 \mathrm{~A}$ & $73 \pm 1.576 \mathrm{~A}$ & $3.2 \pm 0.178 \mathrm{~A}$ & $0.66 \pm 0.067 \mathrm{~A}$ \\
\hline \multirow{3}{*}{$\begin{array}{l}\text { Yeast } \\
\text { extract }\end{array}$} & 2.5 g. $\mathrm{L}^{-1}$ & $57.2 \pm 1.98 \mathrm{C}$ & $5.7 \pm 0.89 \mathrm{C}$ & $1.90 \pm 0.18 \mathrm{CB}$ & $63 \pm 2.5163 \mathrm{C}$ & $2.7 \pm 0.151 \mathrm{~B}$ & $0.58 \pm 0.044 \mathrm{~B}$ \\
\hline & 5 g.L - $^{-1}$ & $58.7 \pm 1.89 \mathrm{C}$ & $6.0 \pm 0.89 \mathrm{~B}$ & $1.95 \pm 0.15 \mathrm{~B}$ & $69 \pm 1.894 \mathrm{~B}$ & $2.8 \pm 0.1894 \mathrm{~B}$ & $0.59 \pm 0.055 \mathrm{~B}$ \\
\hline & 10 g. $\mathrm{L}^{-1}$ & $62.1 \pm 1.87 \mathrm{~B}$ & $6.1 \pm 0.268 \mathrm{~B}$ & $2.02 \pm 0.13 \mathrm{~A}$ & $70 \pm 1.890 \mathrm{~B}$ & $2.9 \pm 0.157 \mathrm{~B}$ & $0.60 \pm 0.048 \mathrm{~B}$ \\
\hline \multicolumn{2}{|c|}{ LSD } & 1.5801 & 0.262 & 0.158 & 1.8359 & 0.2422 & 0.0242 \\
\hline
\end{tabular}

Note: Values aremean of three replications \pm standard deviation. Different letters indicate statistically significant differences at $p \leq 0.05$.

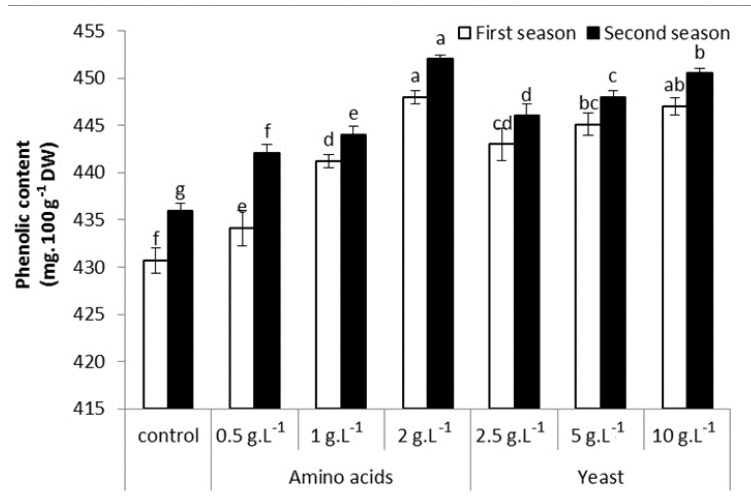

Figure 1 Effect of foliar application of amino acid and yeast extract on phenol contents of hot pepper fruits. Vertical bars show standard deviation $(n=3)$. Different letters indicate statistically significant differences at $p \leq 0.05$.

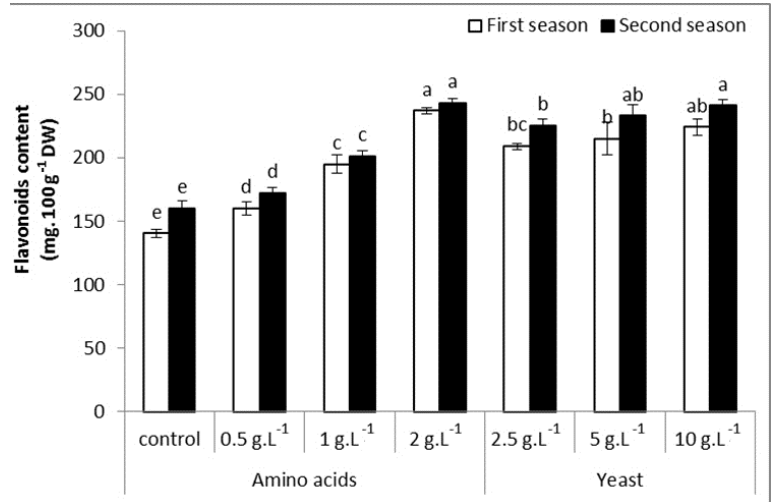

Figure 2 Effect of foliar application of amino acid and yeast extract on flavonoid contents of hot pepper fruits. Vertical bars show standard deviation $(\mathrm{n}=3)$. Different letters indicate statistically significant differences at $p \leq 0.05$. 
These compounds were increased by increasing the concentration of amino acid and yeast extract and this tendency was clear in the both two seasons. In general pepper fruits can provide the types of nutritional and health benefits with consumption of fresh pepper fruit.

Pepper fruits contain complex phenolic compounds binding with sugars and glycosides, also its phenolics content and antioxidant activity have been researched (Materska and Perucka, 2005). The largest concentration of total soluble phenols and flavonoids were discovered with dry yeast extract of 10, 15 and 20 percent in neem plants. (Taha, Ibrahim and Aziz, 2016). The phenolics content of wheat seeds treated by yeast and germinated for four days were increased according to Gawlik-Dziki et al. (2016). It was found that the application of biostimulants resulted in a significant increase in the total phenolic content, sinapic acid content, as well as quercetin content, in the treated plants (Kałużewicz, Gąsecka and Spiżewski, 2017). As far as phenolic compounds are concerned, plant extract increases the phenylpropanoid synthesis enzyme activity which increases phenolic compounds (Ramachandra and Ravishankar, 2002). As well as the derivatives of ferulic and sinapic acids have been determined in pericarp of red pepper fruit $\mathrm{cv}$. Bronowicka Ostra (Materska et al., 2003). Because the profile of phenolic compounds is equally important for biological activity (Anantharaju et al., 2016). Syringic acid is well known for its anti-cancer, anti-proliferative, sedative, decongestant and hepato-protective conduct (Kampa et al., 2004).

Table 3 Profile of phenolic compounds content of hot pepper fruits using HPLC chromatogram as affected by amino acids and yeast extract.

\begin{tabular}{|c|c|c|c|c|c|c|c|c|c|c|c|c|c|c|}
\hline \multirow{3}{*}{$\begin{array}{l}\text { Phenolic } \\
\text { compounds }\end{array}$} & \multicolumn{7}{|c|}{ First seasons } & \multicolumn{7}{|c|}{ Second season } \\
\hline & \multirow[b]{2}{*}{ Control } & \multicolumn{3}{|c|}{ Amino acids } & \multicolumn{3}{|c|}{ Yeast extract } & \multirow[b]{2}{*}{ Control } & \multicolumn{3}{|c|}{ Amino acids } & \multicolumn{3}{|c|}{ Yeast extract } \\
\hline & & $\begin{array}{c}0.5 \\
\text { g. } \mathrm{L}^{-1}\end{array}$ & $\begin{array}{c}1.0 \\
\text { g.L-1 }\end{array}$ & $\begin{array}{l}2.0 \\
\text { g. } \mathrm{L}^{-1}\end{array}$ & $\begin{array}{c}2.5 \\
\text { g. } \mathrm{L}^{-1}\end{array}$ & $\begin{array}{l}5.0 \\
\text { g. } L^{-1}\end{array}$ & $\begin{array}{l}10.0 \\
\text { g. } \mathrm{L}^{-1}\end{array}$ & & $\begin{array}{l}0.5 \\
\text { g. } L^{-1}\end{array}$ & $\begin{array}{l}1.0 \\
\text { g. } \mathrm{L}^{-1}\end{array}$ & $\begin{array}{c}2.0 \\
\text { g. } \mathrm{L}^{-1}\end{array}$ & $\begin{array}{c}2.5 \\
\text { g. } \mathrm{L}^{-1}\end{array}$ & $\begin{array}{c}5.0 \\
\text { g. } \mathrm{L}^{-1}\end{array}$ & $\begin{array}{l}10.0 \\
\text { g. } L^{-1}\end{array}$ \\
\hline Gallic acid & 2.06 & 2.98 & 3.24 & 3.49 & 3.56 & 3.98 & 4.20 & 1.69 & 1.82 & 2.41 & 3.97 & 3.05 & 4.31 & 4.80 \\
\hline Catechol & 2.83 & 2.89 & 2.96 & 3.62 & 3.04 & 3.16 & 3.22 & 2.56 & 2.73 & 2.97 & 3.59 & 3.07 & 3.43 & 3.75 \\
\hline $\begin{array}{l}p \text {-hydroxy } \\
\text { benzoic } \\
\text { acid }\end{array}$ & 11.45 & 20.56 & 26.90 & 32.65 & 15.58 & 19.78 & 27.97 & 13.67 & 16.20 & 22.71 & 29.46 & 16.85 & 20.77 & 25.93 \\
\hline Caffeine & 11.31 & 12.95 & 15.20 & 20.18 & 14.83 & 17.39 & 21.95 & 10.31 & 13.10 & 18.20 & 23.27 & 16.46 & 19.47 & $23.8 \mathrm{C}$ \\
\hline $\begin{array}{c}\text { Vanillic } \\
\text { acid } \\
\end{array}$ & 0.91 & 1.56 & 2.31 & 2.90 & 1.44 & 1.85 & 2.17 & 0.61 & 1.03 & 1.66 & 1.81 & 0.89 & 1.62 & 1.96 \\
\hline Caffeic acid & 0.72 & 0.89 & 0.93 & 2.40 & 1.03 & 2.46 & 3.61 & 0.98 & 1.45 & 1.80 & 2.69 & 0.88 & 1.01 & 1.47 \\
\hline $\begin{array}{l}\text { Syringic } \\
\text { acid }\end{array}$ & 2.89 & 3.56 & 4.27 & 5.92 & 2.93 & 3.81 & 4.59 & 2.21 & 3.11 & 3.33 & 3.75 & 2.40 & 3.81 & 4.26 \\
\hline Vanillin & 1.27 & 2.10 & 2.89 & 3.50 & 1.95 & 2.33 & 2.82 & 1.40 & 2.47 & 3.30 & 3.36 & 3.89 & 3.26 & 3.72 \\
\hline $\begin{array}{c}p \text {-Coumaric } \\
\text { acid }\end{array}$ & 4.58 & 3.39 & 1.85 & 2.52 & 3.94 & 3.32 & 2.07 & 3.76 & 3.94 & 4.25 & 4.65 & 3.49 & 4.85 & 4.15 \\
\hline Ferulic acid & 6.88 & 4.61 & 3.34 & 3.90 & 6.04 & 4.88 & 3.59 & 6.86 & 4.41 & 4.63 & 6.38 & 4.10 & 5.53 & 5.48 \\
\hline Ellagic acid & 2.25 & 2.96 & 1.13 & 1.13 & 1.48 & ND & 2.58 & 1.91 & 2.20 & 1.84 & 2.49 & 2.56 & 2.77 & 2.98 \\
\hline $\begin{array}{c}\text { Benzoic } \\
\text { acid }\end{array}$ & 1.29 & 1.11 & 0.93 & 0.09 & 0.12 & 1.57 & 0.79 & 1.06 & 1.85 & 1.32 & 1.45 & 1.23 & 1.68 & 1.98 \\
\hline $\begin{array}{c}o \text {-Coumaric } \\
\text { acid }\end{array}$ & 1.08 & 0.89 & 1.64 & 0.40 & 0.63 & 0.08 & 0.82 & 1.46 & 1.42 & 1.97 & 2.49 & 1.56 & 1.14 & 0.95 \\
\hline $\begin{array}{c}\text { Salicylic } \\
\text { acid }\end{array}$ & 2.79 & 1.23 & 3.79 & 1.87 & ND & 2.57 & 2.78 & 1.89 & 1.95 & 2.91 & 3.27 & 2.13 & 2.63 & 2.81 \\
\hline $\begin{array}{c}\text { Cinnamic } \\
\text { acid }\end{array}$ & 0.41 & 0.43 & 0.47 & 0.52 & 0.44 & 0.46 & 1.64 & 0.54 & 0.53 & 0.60 & 1.38 & 0.97 & 0.81 & 1.45 \\
\hline
\end{tabular}

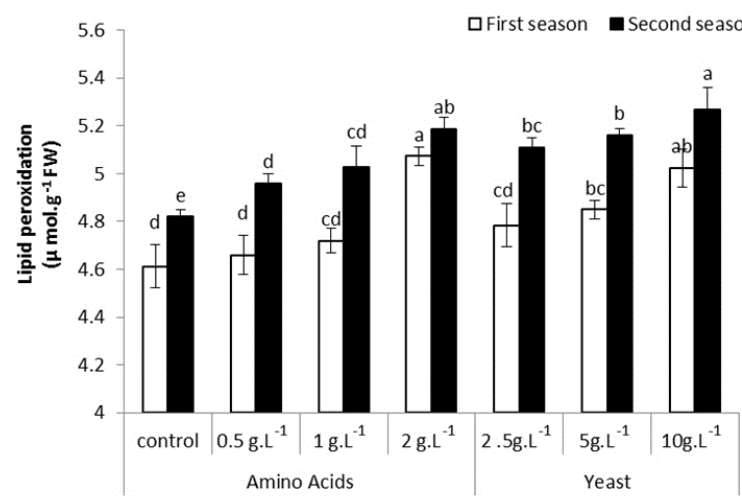

Figure 3 Effect of foliar application of amino acids and yeast extract on lipid peroxidation of hot pepper fruits. Vertical bars show standard deviation $(n=3)$. Different letters indicate statistically significant diffomonons nt $n<n \cap 5$

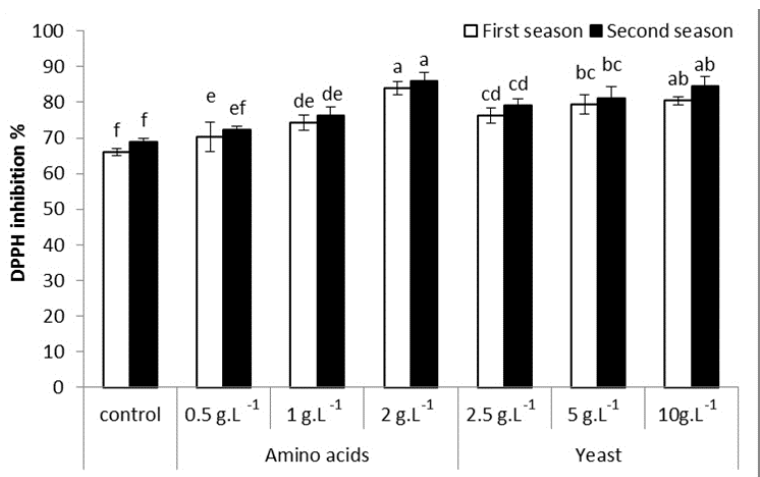

Figure 4 Effect of foliar application of amino acids and yeast extract on 1,1-Diphenyl-2-picrylhydrazyl (DPPH) of hot pepper fruits. Vertical bars show standard deviation $(n=3)$. Different letters indicate statistically 
One of the most important phenolics, ferulic acid, is known for its physiological activities, such as, antimicrobial, anti-inflammatory, anti-cancer etc. It also reduces` serum cholesterol improves the viability of sperm (Mussatto, Dragone and Roberto, 2007). Also, $P$ Coumaric acid, is frequently found in foods such as barley, marine beans, tomatoes carrots, etc. and is welldocumented for its antioxidant behaviour. Antioxidant conduct is thought to reduce cancer nitrosamine formation in the abdomen (Ramadoss Karthikeyan, Chapala and Puttagunta, 2015). It is well known that phenolic compounds possess many biological activities; the prohealth impact of polyphenols is related mainly to their commonly reported antioxidant properties resulting from their ability to neutralize free radicals, disrupt autooxidation chain reactions, chelate transition metal ions, and inhibit the activity of pro-oxidant enzymes (Carocho and Ferreira, 2013). While, Caffeic acid is one of the main compounds of hydroxyl Cinnamic acid present and is a well-known antioxidant that encourages immunity, controls blood lipid and anti-mutagenic levels.

\section{Lipid peroxidation content and free radical scavenging activity (DPPH)}

With respect to the content of lipid peroxidation, Figure 3 showed that $2 \mathrm{~g}$. $\mathrm{L}^{-1}$ foliar amino acids application had the highest content $\left(5.073 \mu \mathrm{mol} \mathrm{MDA} \mathrm{g}{ }^{-1}\right.$ F.W. $)$ in the first season. Whereas, 10 g. $\mathrm{L}^{-1}$ of yeast foliar application had the highest content in the second season $(5.27 \mu \mathrm{mol}$ MDA g ${ }^{-1}$ F.W.). Results obtained in Figure 4 also, showed that in the first and second seasons foliar application 2 g.L $\mathrm{L}^{-1}$ amino acids had the largest inhibition percentage of 1,1-Diphenyl-2-picrylhydrazyl (DPPH). Additionally, exogenous use of crop development regulators has a positive effect on MDA accumulation relative to controls. Plant development regulators play an efficient part in preserving fruit cell membranes fluidity and integrity. The equilibrium between the production and detoxification of ROS is sustained by enzymatic and nonenzymatic antioxidants. The highest antioxidant activities estimated as free radical scavenging activity against DPPH and reducing power were increased of treated quinoa seeds by yeast extract (Abdallah, Habbasha and El Sebai, 2016).

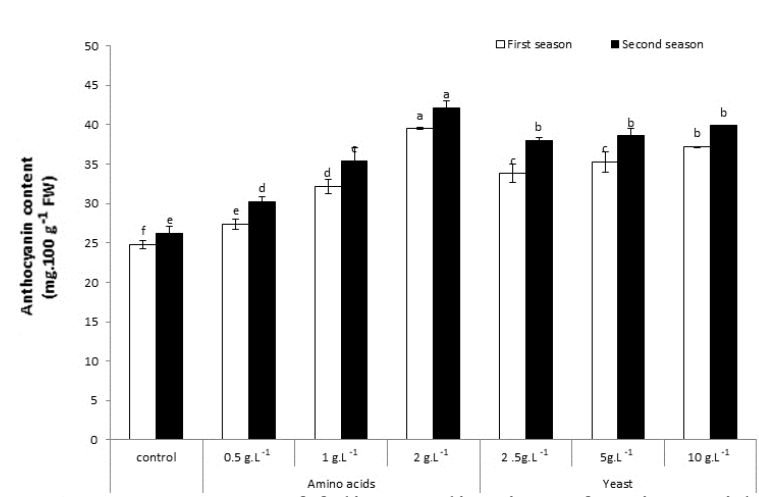

Figure 5 Impact of foliar application of amino acids and yeast extract on anthocyanins content of hot pepper fruits. Vertical bars show standard deviation $(\mathrm{n}=3)$. Different letters indicate statistically significant differences at $p \leq 0.05$.

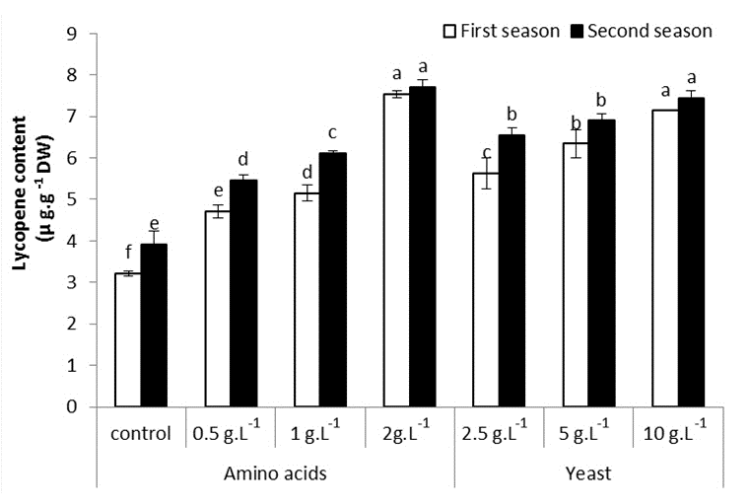

Figure 7 Impact of foliar application of amino acids and yeast extract on lycopene content of hot pepper fruits. Vertical bars show standard deviation $(n=3)$. letters indicate statistically significant differences at $p \leq 0.05$.

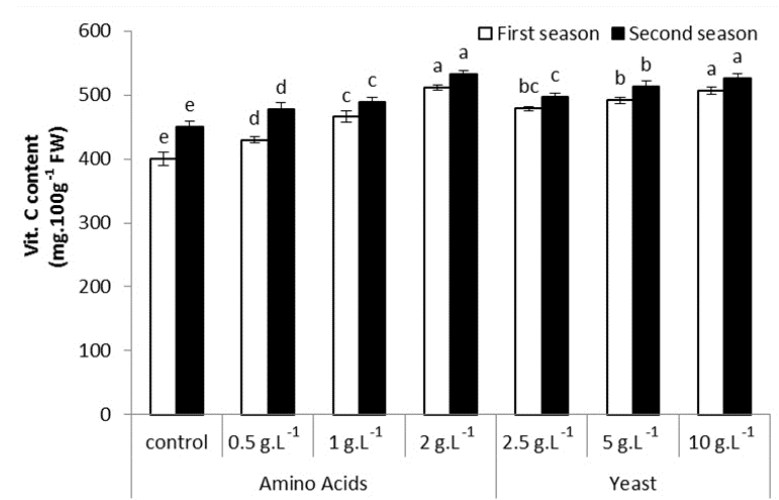

Figure 6 Impact of foliar application of amino acids and yeast extract on vitamin $\mathrm{C}$ content of hot pepper fruits. Vertical bars show standard deviation $(n=3)$. Different letters indicate statistically significant differences at $p \leq 0.05$.

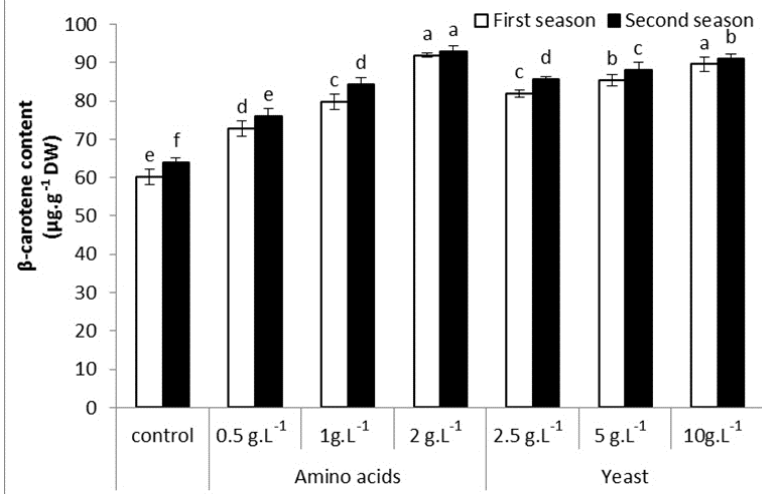

Figure 8 Impact of foliar application of amino acids and yeast extract on $\beta$ - carotene of hot pepper fruits. Vertical bars show standard deviation $(n=3)$. Different letters indicate statistically significant differences at $p \leq 0.05$. 
Anthocyanins, Vitamin $\mathrm{C}$, lycopene and $\beta$ carotene.

Differences in anthocyanins content among hot pepper were noted as influenced by amino acids foliar application and yeast extract (Figure 5). The results showed that in the first and the second seasons (39.49 and $42.14 \mathrm{mg} \cdot 100 \mathrm{~g}^{-1}$ F.W.) the anthocyanins content of hot pepper fruits increased with foliar implementation of amino acids (2 g.L $\left.\mathrm{L}^{-1}\right)$. As well as 10 g.L $\mathrm{L}^{-1}$ yeast extract foliar application showed the highest anthocyanins content in the first and second seasons, (37.20 and $39.87 \mathrm{mg}^{100 \mathrm{~g}^{-1}}$ F.W.) respectively. The results in (Figure 6) also showed that in first and second seasons, foliar application with (2 g. $\left.\mathrm{L}^{-1}\right)$ amino acid had the highest ascorbic acid content (512 and $533 \mathrm{mg} .100 \mathrm{~g}^{-1}$ F.W.), respectively compared to the control. The content of lycopene improved with foliar implementation of amino acids, and the highest rise was noticed in both seasons with 2 g.. $\mathrm{L}^{-1}$ amino acid (7.53 and $7.70 \mu \mathrm{g} . \mathrm{g}^{-1}$ D.W.). Otherwise, 10 g.L $\mathrm{L}^{-1}$ foliar yeast extract application yielded the highest lycopene content in the first and second seasons (7.14 and $7.44 \mu \mathrm{g} . \mathrm{g}^{-1}$ D.W.), respectively as declared in (Figure 7). In the first and second seasons, $\beta$-carotene content increased with 2 g.L. $\mathrm{L}^{-1}$ foliar amino acid application (91.9 and $93 \mu \mathrm{g} . \mathrm{g}^{-1}$ D.W.), respectively. While, for the first and second seasons the content of 10 g.L $\mathrm{L}^{-1}$ of yeast extract reduced to (89.6 and $91.1 \mu \mathrm{g} . \mathrm{g}^{-1}$ D.W.), respectively (Figure 8). Belal, ElKenawy and Uwakiem (2016) stated that spraying flameless grapevines three times with single or combined methionine, glutamic acid and argentine, considerably enhanced complete anthocyanins and total phenols. The promotional impact of amino acids on the development and fruiting of flameless grapevines could be ascribed to their beneficial action to protect crops from oxidative stress, improving proteins biosynthesis by polymerizing amino acids, ethylene, $\mathrm{GA}_{3}$, IAA, cyokinins, pigments of crops, and organic foods (Davies, 1982). Meanwhile, Abou-Zeed et al. (2014) found that the use of yeast extract has been helpful in enhancing the vegetative vigour and nutritional status of Balady Mandarin trees leading to increase yield and improv the fruit quality and contents of vitamin C. As indicated in other studies, the use of yeast extract resulted in increased production of ascorbic acid (Zlotek, 2017). Otherwise, Abo Sedera et al. (2010) found that spraying strawberry crops by amino acids (peptone) considerably improved fruit vitamin $\mathrm{C}$ relative to control treatment at 0.5 and 1.0 g.L $\mathrm{L}^{-1}$. Shafeek, Ellaithy and Helmy (2014) discovered in the same concern that hot pepper vitamin $\mathrm{C}$ was promoted by increased the amount of yeast extract from 2 g.L. $\mathrm{L}^{-1}$ to 4 g. $\mathrm{L}^{-1}$ but this rise did not achieve the important amount.

\section{CONCLUSION}

The use of biostimulants as amino acids and yeast extracts stimulate the growth of crops to overcome the harmful effect of some environmental stress. The findings revealed that foliar of amino acid or yeast extract application improved the growth parameters of hot pepper compared to control in both the first and second seasons, particularly foliar amino acid $\left(2\right.$ g.L. $\left.\mathrm{L}^{-1}\right)$ or yeast $(10$ g.L.- $)$ implementation. With foliar application of amino acid or yeast extract improved phenol, flavonoid, anthocyanins, ascorbic acid, lycopene and $\beta$-carotene relative to control in the first and second seasons. Foliar application 2 g.L. ${ }^{-1}$ amino acids had the greatest 1,1-Diphenyl-2picrylhydrazyl (DPPH) inhibition proportion and the highest lipid peroxidation content. The HPLC techniques that represent the impact of foliar application of amino acid or yeast have elucidated the derivatives of phenolic compounds. Phenolic compounds were increased by increasing the concentration of amino acid and yeast extract foliar application in the both two seasons.

\section{REFERENCES}

A.O.A.C. 2000. Official Methods of Analysis of the Association of Official Analytical Chemists. $17^{\text {th }}$ ed. USA : Association of Official Analytical Chemists.

Abdallah, M. M. S., El Habbasha, S. F., El Sebai, T. 2016. Comparison of yeast extract and nicotinaminde foliar applications effect on quinoa plants grown under sandy soil condition. International Journal of PharmTech Research, vol. 9, p. 24-32.

Abo Sedera, F., Amany, A., Abd El-Latif, A., Bader, L. A. A., Rezk, S. M. 2010. Effect of NPK mineral fertilizer levels and foliar application with humic and amino acids on yield and quality of strawberry. Egyptian Journal of Applied Science, vol. 25, p. 154-169.

Abou-Zeed, E. A. A., El-Salhy, A. M., Abdel-Galil, H. A., Badawy, E. F. M. 2014. Effect of yeast and different phosphorus fertilizer sources on growth and fruiting of balady mandarin Trees. Assiut Journal of Agriculture Science, vol. 45, no. 3, p. 49-64. https://doi.org/10.21608/ajas.2014.869

Anantharaju, P. G., Gowda, P. C., Vimalambike, M. G., Madhujapantula, S. V. 2016. An overview and the role of dietary phenolic for the treatments. Nutrtion Journal, vol. 15, no. 1, p. 99. https://doi.org/10.1186/s12937-016-0217-2

Belal, B. E., El-Kenawy, M. A., Uwakiem, M. K. 2016. Foliar application of some smino scids and vitamins to improve growth, physical and chemical properties of flame seedless grapevines. Egyptian Journal of Horticure, vol. 43, no. 1, p. 123-136. https://doi.org/10.21608/ejoh.2016.2831

Buege, J. A., Aust, S. D. 1978. Microsomal lipid peroxidation. Methods of Enzymolgy, vol. 52, p. 302-310. https://doi.org/10.1016/S0076-6879(78)52032-6

Caporaso, N., Paduano, A., Nicoletti, G., Sacchi, R. 2013. Capsaicinoids, antioxidant activity, and volatile compounds in olive oil flavoredwithdriedchili pepper (Capsicum annuum). Eurpian Journal of Lipid Science and Technology, vol. 115, no. 12 , p. 1434-1442. https://10.1002/ejlt.201300158

Carocho, M., Ferreira, I. C. F. R. 2013. A review on antioxidants, prooxidants and related controversy, natural and synthetic compounds, screening and analysis methodologies and future perspectives. Food Chemistry Toxicol., vol. 51, p. 15-25. https://doi.org/10.1016/j.fct.2012.09.021

Cerdán, M. A., Sánchez-Sánchez, A. F., Oliver, M. D., Juárez, M. T., Sánchez-Andreu, J. J. 2009. Effect of foliar and root applications of amino acids on iron uptake by tomato plants. J. Acta Hort., vol. 830, p. 481-488. https://doi.org/10.17660/ActaHortic.2009.830.68

Davies, D. D. 1982. Physiological aspects of protein turn over. Encyclopedia of Plant Physiology, vol. 45, p. 481-487. https://doi.org/10.1007/978-3-642-68237-7

Du, C. T., Francis, F. J. 1973. Anthocyanins of Roselle (Hibiscus sabdariffa L.). Journal of. Food Scince, vol. 38, p. 810-812. https://doi.org/10.1111/j.1365-2621.1973.tb02081.x

Duncan, B. D. 1955. Multiple range and multiple F tests. Biometrics, vol. 11, p. 1. https://doi.org/10.2307/3001478 
Fuleki, T., Francis, F. J. 1968. Extraction and determination of total anthocyanin in cranberries. J. Food Sci., vol. 33, no. $1, \quad$ p. 72-77. https://doi.org10.1111/j.13652621.1968.tb00887.x

Gawlik-Dziki, U., Dziki, D., Nowak, R., Świeca, M., Olech, M. 2016. Influence of sprouting and elicitation on phenolic acids profile and antioxidant activity of wheat seedlings. Journal of Cereal Scince, vol. 70, p. 221-228. https://doi.org/10.1016/j.jcs.2016.06.011

Gulluce, M., Sokmen, M., Sahin, F., Sokmen, A., Adiguzel, A., Ozer, H. 2004. Biological activities of the essential oil and methanolic extract of Micromeria fruticosa (L) Druce ssp serpy llifolia (Bieb) $\mathrm{PH}$ davis plants from the Eastern Anatolia region of Turkey. Journal Scince Food Agriculture, vol. 84, p. 735. https://doi.org/10.1002/jsfa.1728

Igbokwe, G. E., Aniakor, G. C., Anagonye, C. O. 2013. Determination of $\beta$-Carotene \& Vitamin $C$ content of Fresh Green Pepper (Capsicum annnum), Fresh Red Pepper (Capsicum annum) and Fresh Tomatoes (Solanum lycopersicum) Fruits. Bioscientist., vol. 1, p. 89-93.

Jungklang, J., Songklanakarin, K. S. 2012. Effect of paclobutrazol on Patumma cv. Chiang Mai Pink under water stress. Journal Science Technology, vol. 34, p. 361-366.

Kałużewicz, A., Gąsecka, M., Spiżewski, T. A. 2017. Influence of biostimulants on phenolic content in broccoli heads directly after harvest and after storage. Folia Hort., vol. 29, no. 2, p. 221-230. https://doi.org/10.1515/fhort-2017-0020

Kampa, M., Alexaki, V., Notas, G., Nifli, A., Nistikaki, A., Hatzoglou, A., Bakogeorgou, E., Kouimtzoglou, E., Blekas, G., Boskou, D., Gravanis, A., Castanas, E. 2004. Antiproliferative and apoptotic effects of selective phenolic acids on T47D human breast cancer cells: potential mechanisms of action. Breast Cancer Research, vol. 6, no. 2, p. 63-R74. https://doi.org/10.1186/bcr752

Korkmaz, A. R., Ferit Kocac, D. S., Ozlem De־gera, S. A., Demirkırıand, A. R. 2012. Alleviation of salt-induced adverse effects in pepper seedlings by seed application of glycinebetaine. J. Sci. Hort., vol. 148, p. 197-205. https://doi.org/10.1016/j.scienta.2012.09.029

Mahmoud, A. R., Hafez, M. M. 2010. Increasing productivity of potato plants (Solanum tuberosum L.) by using potassium fertilizer and humic acid application. Intnational Journal of Academic Research, vol. 2, p. 83-88.

Maraei, R., Eliwa, N., Aly, A. 2019. Use of some biostimulants to improve the growth and chemical constituents of sweet pepper. Potravinarstvo Slovak Journal of Food Sciences., vol. 13, no. 1, p. 553-561. https://doi.org/10.5219/1131

Marhoon, I. A., Abbas, M. K. 2015. Effect of foliar application of Seaweed extract and amino acids on some vegetative and anatomical characters of sweet pepper (Capsicum Annuum L.) cultivars. Intnational Journal of Reserch Studies in Agricutural Scince, vol. 1, p. 35-44.

Marinova, D., Ribarova. F., Tanassova, M. 2005. Total phenolic and total flavonoids in Bulgarian fruits and vegetables. Journal of Univistry Chemistry Technology Metallurgy, vol. 40, no. 3, p. 255-260.

Martínez, S., Curros, A., Bermúdez, J., Carballo, J., Franco, I. 2007. The composition of Arnoia peppers (Capsicum annuum L.) at different stages of maturity. Internatonal Journal of Food Scince and Technology, vol. 58, p. 150-161. https://doi.org/10.1080/09637480601154095.

Materska, M., Perucka, I. 2005. Antioxidant activity of the main phenolic compounds isolated from hot pepper fruit (Capsicum annuum L.). Journal of Agriculture of Food
Chemistry, vol. 53,
https://doi.org/10.1021/jf035331k

p.

$1750-1756$

Materska, M., Perucka, I., Stochmal, A., Piacente, S., Oleszek, W. 2003. Quantitative and qualitative determination of flavonoids and phenolic acid derivatives from pericarp of hot pepper fruit cv. Bronowicka Ostra. Polish Journal of Food Nutrtion Scince, vol. 12, no. 53, p. 72-76.

Mohamed, A. M. 2006. Effect of Some Bio-chemical Fertilization Regimes on Yield of Maize : dissertation theses. Egypt, Ash Shargija : Zagazig University, p. 70-177.

Mohamed, S. E. 2005. Photochemical studies on common bean (Phaseolus vulgaris, L.) plants as affected by foliar fertilizer and active dry yeast under sandy soil conditions. Egypt Journal Applied Scince, vol. 20, no. 5, p.539-559.

Mussatto, G., Dragone, I., Roberto, C. 2007. Ferulic and pcoumaric acids extraction by alkaline hydrolysis of brewer's spent grain. Ind. Crops Pro., vol. 25, no. 2, p. 231-237. https://doi.org/10.1016/j.indcrop.2006.11.001

Nagata, M., Yamashita, I. 1992. Simple method for simultaneous determination of chlorophyll and carotenoids in tomato fruit. Journal of Food Scince Technology, vol. 39, no. 10, p. 925-928. https://doi.org/10.3136/nskkk1962.39.925

Nuutila, A. M., Puupponen-Pimia, R., Aarni, M., OksmanCaldentey, K. M. 2003. Comparison of antioxidant activities of onion and garlic extracts by inhabitation of lipid peroxidation and radical scavenging activities. Food Chemistry, vol. 81, no. 4, p. 485-493. https://doi.org/10.1016/S0308-8146(02)00476-4

Palma, J. M., Francisca, S., Jimeénez, A., del Ri'o, A. J., Corpas, J. F., A'lvarez de Morales, P., Camejo, D. M. 2015. Physiology of pepper fruit and the metabolism of antioxidants: chloroplasts, mitochondria and peroxisomes. Annals of Botany, vol. 116, no. 4, p. 627-636. https://doi.org/10.1093/aob/mcv121

Popelka, P., Jevinová, P, Šmejkal, K., Roba, P. 2017. Antibacterial activity of capsicum extract against selected strains of bacteria and micromycetes. Potravinarstvo Slovak Journal of Food Sciences., vol. 11, no. 1, p. 223-229. https://doi.org/10.5219/731

Ramachandra, R. S., Ravishankar., G. A. 2002. Plant cell cultures: chemical factories of secondary metabolites. Biotechnology Advances, vol. 20, no. 2, p. 101-153. https://doi.org/10.1016/S0734-9750(02)00007-1

Ramadoss Karthikeyan, S. I., Chapala, D., Puttagunta, S. B. 2015. Isolation, characterization, and RP-HPLC estimation of $P$-coumaric acid from methanolic extract of Durva Grass (Cynodondactylon Linn.) (Pers.). International journal of Analatical Chemistry, vol. 2015, p. 1-7. http://doi.org/10.1155/2015/201386

Serna, M. Y., Ndez, F. H., Coll, F. A., Coll, Y. T., Amoro, A. D. 2012. Brassinosteroid analogues effects on the yield and quality parameters of greenhouse-grown pepper (Capsicum annuum L.). Journal of Plant Growth Regulator, vol. 68, no. 3, p. 333-342. https://doi.org/10.1007/s10725012-9718-y

Shafeek, M. R., Ellaithy, A. Y. M., Helmy, Y. I. 2014. Effect of bio fertilizer and some microelements on insect and mite pest infestation, growth, yield and fruit quality of hot pepper (Capsicum annum, L.) grown under plastic house condition. Middle East Journal of Agriculture Research, vol. 3 , no. 4, p.1022-1030.

Shahidi, F., Naczk, M. 1995. Methods of analysis and quantification of phenolic compounds. Food phenolic: sources, chemistry, effects and applications. Lancaster : Technomic Publishind Company, Inc., p. 287. ISBN 9781566762793. 
Soobrattee, M. A., Neergheen, V. S., Luximon-Rammaa, A., Aruomab, O. I., Bahorun, T. 2005. Phenolics as potential antioxidant therapeutic agents: Mechanism and actions. Mutation Research, vol. 579, no. 1-2, p. 200-213. https://doi.org/10.1016/j.mrfmmm.2005.03.023

Taha, L. S., Ibrahim, S. M. M., Aziz, N. G. A. 2016. Vegetative growth, chemical composition, and flavonoids content of Azadirachta indica plants as affected by application of yeast natural extract. Journal of Applied Pharmaceutical Scince, vol. 6, no. 4, p. 093-097. https://doi.org/10.7324/JAPS.2016.60413

Zhang, L., Zhou, J., Zhao, Y. G., Zhai, Y., Wang, K., Alva, A. K., Paramasivam, S. 2013. Optimal combination of chemical compound fertilizer and humic acid to improve soil and leaf properties, yield and quality of apple (Malus domestica). Pakistan Journal of Botany, vol. 45, no. 4, p. 1315-1320.

Zlotek, U. 2017. Effect of Jasmonic Acid and yeast extract elicitation on low-molecular antioxidants and antioxidant activity of Marjoram (Origanum majorana L.). Acta Scientiarum Polonorum Technologia Alimentaria, vol. 16, no. 4, p. 371-377. https://doi.org/10.17306/J.AFS.2017.0505

\section{Acknowledgments:}

Authors would like to thank the Atomic Energy Authority for their support and funding this study.

\section{Contact address:}

*Amina Aly, Natural Products Dept., National Center for Radiation Research and Technology, Atomic Energy Authority, P.O. 29, Nasr City, Cairo- Egypt, Tel.: + 20222749298,

E-mail: aly_amina@yahoo.co.uk

ORCID: https://orcid.org/000-0003-0756-731x

Noha Eliwa, Natural Products Dept., National Center for Radiation Research and Technology, Atomic Energy Authority, P.O. 29, Nasr City, Cairo- Egypt, Tel.: + 20222749298

E-mail: nohaeliwa@hotmail.com

ORCID: https://orcid.org/0000-0002-9897-318X

Mohamed Hassan Abd El Megid., Natural Products Dept., National Center for Radiation Research and Technology, Atomic Energy Authority, P.O. 29, Nasr City, Cairo- Egypt, Tel.: + 202-22749298,

E-mail: Hassan.m3231@yahoo.com

ORCID: -

Corresponding author: * 